УДК: 636.4.082.453.52

doi: $10.36359 /$ scivp.2019-20-2.45

\title{
ЯКІСТЬ ЕЯКУЛЯТІВ КНУРІВ, ЗАЛЕЖНО ВІД ПОХОДЖЕННЯ
}

\author{
С. Б. Корнят ${ }^{1}$, канд. с.-г. наук, \\ Н. В. Кузьміна, канд. біол. наук, \\ M. М. Шаран ${ }^{1}, \partial-p$ c.-г. н. \\ Д. Д. Ocmanis ${ }^{1}$, д-р с.-г. наук

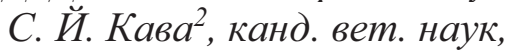 \\ O. I. Чайковська ${ }^{3}$, канд. біол. наук, \\ О. П. Панич ${ }^{3}$, канд. вет. наук, \\ I. С. Атаманюк ${ }^{3}$ стариий науковий співробітник, \\ T. I. Стецькоз, канд. с.-г. наук \\ ${ }^{1}$ Інститут біології тварин НААН \\ вул. Стуса, 38, м. Львів, 79034, Україна \\ ${ }^{2}$ Львівський національний університет ветеринарної медицини та біотехнологій \\ імені С. 3. Гжицького \\ вул. Пекарська, 50, м. Львів, 79010, Україна \\ ${ }^{3}$ Державний науково-дослідний контрольний інститут ветеринарних препаратів \\ та кормових добавок \\ вул. Донецька, 11, м. Львів, 79019, Україна
}

Досліджували фізіолого-біохімічні характеристики еякулятів кнурів у зв'язку з породною належністю (n’єтрен, макстер, ландрас, дюрок $i$ помісь: велика біла порода хландрас). Встановлено, щзо фізіологічні показники якості еякулятів залежать від породи кнурів. Вищим об'ємом еякуляту характеризуються помісні кнурі велика біла

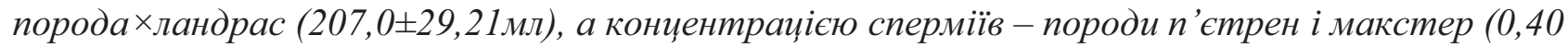
- 0,43×109/мл). Кількість живих спермї̈в в еякулятах кнурів досліджених порід не відрізнялась $(78,7-80,3 \%)$.

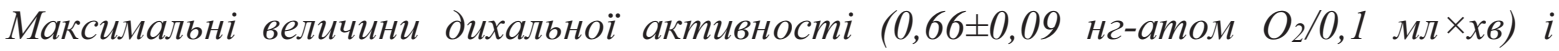
активності СДГ $(17,9 \pm 3,43$ од/0,1 мл ×год) характерні для сперми кнурів породи дюрок, а

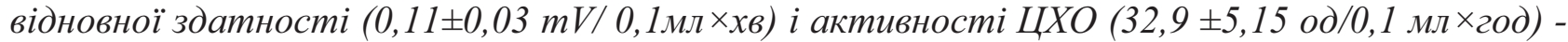
для породи макстер. Найвище виживання сперміїв (90,3 - 92,0 год) встановлено у спермі кнурів порід макстер та ландрас.

Ключові слова: ЯКІСТЬ ЕЯКУЛЯТІВ, СПЕРМІЇ, ПОРОДА, КНУРІ.

Серед численних факторів, які визначають якісні характеристики і запліднювальну здатність сперміїв $є$ породна належність кнурів. Зокрема, встановлено залежність фізіологічних характеристик якості еякулятів від породи кнурів: об'єму (у великої білої - 203 мл, ландрас - 227, миргородської - 203), концентрації сперміїв (відповідно, 0,198, 0,217, $0,196 \times 10^{9} /$ клітин) і запліднювальної здатності $(79,9,83,2,79,6 \%)$. Аналогічно, у кнурів породи дюрок об'єм еякуляту - 156-165 мл, а концентрація сперміїв - 0,49×10\%/клітин і запліднювальна здатність - 90,9 \% $[1,2]$. Крім того, якість еякулятів і запліднювальна здатність сперміїв кнурів відрізняється в межах однієї породи [3].

Виявлено, що становлення якості спермопродукції також залежить від породної належності [4]. Так, кількість живих сперміїв у еякуляті зростає з 5 до 8 місяців у 7,7 (p<0,001) раза у червоної білопоясої, в 12,5 раза $(\mathrm{p}<0,001)$ - у полтавської м’ясної і в 8,5 раза $(\mathrm{p}<0,001)$ - в української м'ясної порід. Кількість живих сперміїв у еякуляті у 8 місяців, порівняно 35 
місячними, вища в 10 раз (p<0,001) в української степової білої та в 6,3 раза $(\mathrm{p}<0,001)$ у великої білої порід. Крім фізіологічних характеристик якості еякулятів, породна належність кнурів проявлясться й особливостями біохімічних процесів в спермі [5] Зокрема, встановлена відмінність вмісту природних антиоксидантів і активності ензимів антиоксидантного захисту та нагромадження продуктів пероксидного окиснення ліпідів в еякулятах залежно від напрямку продуктивності (універсального, м'ясного і сального).

Мета досліджень - вивчити фізіологічні й біохімічні характеристики якості еякулятів у зв'язку 3 породною належністю кнурів.

Матеріал і методи. Дослідження проведені в Інституті біології тварин НААН, Державному науково-дослідному контрольному інституті ветеринарних препаратів та кормових добавок та ЛНВЦ «Західплемресурси». Сперму отримували мануальним способом 3 режимом використання кнурів два рази на тиждень. Для досліджень відбирали еякуляти самців порід дюрок, ландрас, п’єтрен, макстер та помісей: велика біла породахландрас i оцінювали за об'ємом (мл), концентрацією сперміїв $\left(10^{9}\right.$ клітин/мл) та кількістю живих статевих клітин (\%). В спермі визначали: виживання сперміїв (год) за температури $2-4^{\circ} \mathrm{C}$ до припинення поступального руху, дихальну активність - полярографічно (нг-атом $\mathrm{O}_{2} / \mathrm{xв} \times 0,1$ мл сперми) [6] і відновну здатність - потенціометрично ( $\mathrm{mV} / \mathrm{xв} \times 0,1$ мл сперми) [7], активність сукцинатдегідрогенази (СДГ) і цитохромоксидази (ЦХО; од/год×0,1 мл сперми) [8]. Статистичний аналіз цифрового матеріалу проведено за М. О. Плохінським [9].

Результати й обговорення. Найвищий об'єм еякуляту характерний для помісних

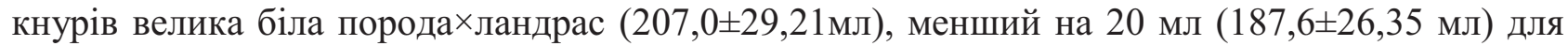
породи макстер і ще на 45 - 56 мл (151,3 - 162,8 мл) - для кнурів порід дюрок, ландрас і п’єтрен (табл. 1).

Таблиия 1

Фізіологічна характеристика якості еякулятів кнурів залежно від породної належності

\begin{tabular}{|c|c|c|c|c|c|c|c|c|c|}
\hline \multirow[t]{2}{*}{ Породи } & \multicolumn{3}{|c|}{ Об’єм еякуляту, мл } & \multicolumn{3}{|c|}{$\begin{array}{c}\text { Концентрація } \\
\text { сперміїв, } 10^{9} / \text { мл }\end{array}$} & \multicolumn{3}{|c|}{$\begin{array}{c}\text { Кількість живих } \\
\text { сперміїв, \% }\end{array}$} \\
\hline & $\mathrm{n}$ & $\mathrm{M} \pm \mathrm{m}$ & $\mathrm{CV}$ & $\mathrm{n}$ & $\mathrm{M} \pm \mathrm{m}$ & $\mathrm{CV}$ & $\mathrm{n}$ & $\mathrm{M} \pm \mathrm{m}$ & $\mathrm{CV}$ \\
\hline П'єтрен & 14 & $151,3 \pm 7,85$ & 18,7 & \begin{tabular}{l|}
1 \\
8
\end{tabular} & $0,43 \pm 0,04$ & 43,5 & 9 & $78,7 \pm 1,28$ & 4,9 \\
\hline Макстер & 5 & $187,6 \pm 26,35$ & 31,4 & \begin{tabular}{l|}
1 \\
2 \\
\end{tabular} & $0,40 \pm 0,04$ & 30,5 & 7 & $80,3 \pm 2,40$ & 7,9 \\
\hline Ландрас & 5 & $157,4 \pm 16,31$ & 23,2 & 6 & $0,37 \pm 0,08$ & 54,4 & 5 & $80,0 \pm 1,98$ & 5,5 \\
\hline Дюрок & 6 & $162,8 \pm 6,99$ & 10,5 & $\begin{array}{l}1 \\
0\end{array}$ & $0,26 \pm 0,04^{* *}$ & 55,3 & 5 & $79,2 \pm 1,53$ & 4,3 \\
\hline Помісь: велика біла поро & 6 & $207,0 \pm 29,21$ & 34,5 & 7 & $0,33 \pm 0,05$ & 38,7 & 5 & $79,6 \pm 1,25$ & 3,5 \\
\hline
\end{tabular}

Примітка: в цій та наступних таблицях різниця статистично вірогідна порівняно до максимальної величини значення показника: ${ }^{*}-\mathrm{p}<0,05, * *-\mathrm{p}<0,01, * * *-\mathrm{p}<0,001$.

Подібні відмінності встановлені за дослідження концентрації сперміїв: максимальна величина значення показника $(0,40$ - 0,43×109/мл) в еякулятах кнурів порід п’єтрен і макстер, нижча на 14 - 23,3 \% у ландрас і помісних кнурів велика біла породахландрас і найнижча $\left(0,26 \pm 0,04 \times 10^{9} /\right.$ мл) - у дюрок. Різниця між максимальною концентрацією клітин в еякулятах кнурів порід п’єтрен і макстер та мінімальною - у дюрок статистично вірогідна $(\mathrm{p}<0,05-$ 0,01). Кількість живих сперміїв в еякулятах, залежно від породи кнурів, вірогідно не відрізнялась і знаходилась в межах 78,7 - 80,3 \%. Отже, аналіз фізіологічних показників якості еякулятів свідчить, що вищий об'єм характерний для помісних кнурів велика біла породахландрас, а концентрація сперміїв - для породи п’єтрен. Кількість живих сперміїв в еякулятах кнурів досліджених порід не відрізняється.

Дихальна активність сперми низька $\left(0,32 \pm 0,06\right.$ нг-атом $\mathrm{O}_{2} / 0,1$ мл $\times$ хв) у кнурів породи п’єтрен, вища на 20,0 \% у макстер і помісних, а найвища $\left(0,66 \pm 0,09\right.$ нг-атом $\mathrm{O}_{2} / 0,1$ мл×хв) у самців породи дюрок (табл.2). 
Дихальна активність і відновна здатність сперми кнурів залежно від породної належності

\begin{tabular}{|c|c|c|c|c|c|}
\hline \multirow[t]{2}{*}{ Порода } & \multirow[t]{2}{*}{$\mathrm{n}$} & \multicolumn{2}{|c|}{$\begin{array}{l}\text { Дихальна активність, } \\
\text { нг-атом } \mathrm{O}_{2} / 0,1 \text { мл×хв }\end{array}$} & \multicolumn{2}{|c|}{$\begin{array}{c}\text { Відновна здатність, } \\
\mathrm{mV} / 0,1 \text { мл×хв }\end{array}$} \\
\hline & & $\mathrm{M} \pm \mathrm{m}$ & $\mathrm{CV}$ & $\mathrm{M} \pm \mathrm{m}$ & $\mathrm{CV}$ \\
\hline П'єтрен & 8 & $0,32 \pm 0,06^{* *}$ & 50,9 & $0,08 \pm 0,01$ & 49,2 \\
\hline Макстер & 11 & $0,40 \pm 0,05^{*}$ & 39,4 & $0,11 \pm 0,03$ & 80,3 \\
\hline Ландрас & 6 & $0,55 \pm 0,06$ & 26,2 & $0,05 \pm 0,01^{*}$ & 44,3 \\
\hline Дюрок & 4 & $0,66 \pm 0,09$ & 26,6 & $0,05 \pm 0,01^{*}$ & 44,9 \\
\hline Помісь: велика біла порода ×ландрас & 8 & $0,41 \pm 0,05^{*}$ & 37,6 & $0,09 \pm 0,01$ & 33,5 \\
\hline
\end{tabular}

Різниця між максимальною величиною дихальної активності сперми кнурів породи дюрок і пониженою - у п’єтрен, макстер й помісних статистично вірогідна $(\mathrm{p}<0,05-0,01)$. При цьому, відновна здатність сперми низька $(0,05 \pm 0,01 \mathrm{mV} / 0,1$ мл×хв) у порід дюрок $\mathrm{i}$ ландрас, вища на 37,5 \% у п’єтрен і помісних кнурів велика біла порода×ландрас, а найвища $(0,11 \pm 0,03 \mathrm{mV} / 0,1$ мл×хв) в еякулятах породи макстер. Різниця між величинами значень відновної здатності у спермі кнурів порід дюрок і ландрас та помісних статистично вірогідна $(\mathrm{p}<0,05)$. Активність СДГ максимально висока $(17,9 \pm 3,43$ од/0,1 мл× год) у спермі кнурів породи дюрок, нижча на 12,9 - 20,7 \% в еякулятах породи п'єтрен і помісних: велика біла порода×ландрас і ще менша (на 53,1 - 57,0 \%; p < 0,05) - у спермі кнурів порід макстер і ландрас (табл. 3).

Табличя 3

Активність окисних ензимів і виживання сперміїв кнурів залежно від породної приналежності

\begin{tabular}{|c|c|c|c|c|c|c|c|c|}
\hline \multirow{3}{*}{ Порода } & \multicolumn{5}{|c|}{ Активність ензимів, од/0,1 мл× год } & \multirow{2}{*}{\multicolumn{3}{|c|}{$\begin{array}{c}\text { Виживання за } 0-4{ }^{\circ} \mathrm{C} \text {, } \\
\text { год }\end{array}$}} \\
\hline & \multicolumn{3}{|c|}{ СДГ } & \multicolumn{2}{|c|}{ ЦХО } & & & \\
\hline & $\mathrm{n}$ & $\mathrm{M} \pm \mathrm{m}$ & $\mathrm{CV}$ & $\mathrm{M} \pm \mathrm{m}$ & $\mathrm{CV}$ & $\mathrm{n}$ & $\mathrm{M} \pm \mathrm{m}$ & $\mathrm{CV}$ \\
\hline П'єтрен & 14 & $15,6 \pm 3,64$ & 84,2 & $32,0 \pm 4,65$ & 54,4 & 26 & $85,8 \pm 5,79$ & 33,7 \\
\hline Макстер & 13 & $7,7 \pm 1,40^{*}$ & 62,9 & $32,9 \pm 5,15$ & 56,5 & 17 & $90,3 \pm 4,99$ & 22,1 \\
\hline Ландрас & 5 & $8,4 \pm 2,01^{*}$ & 53,6 & $21,7 \pm 4,91$ & 39,2 & 6 & $92,0 \pm 6,73$ & 17,9 \\
\hline Дюрок & 8 & $17,9 \pm 3,43$ & 54,6 & $19,0 \pm 6,07$ & 71,4 & 10 & $74,4 \pm 9,26$ & 39,4 \\
\hline Помісь: велика біла порода ×ландрас & 10 & $14,2 \pm 2,98$ & 66,3 & $21,7 \pm 4,36$ & 49,2 & 10 & $84,0 \pm 7,78$ & 29,3 \\
\hline
\end{tabular}

На противагу, активність ЦХО у спермі кнурів породи дюрок низька (19,0土6,07 од/0,1 мл× год), вища на 12,5 \% у ландрас і помісних: велика біла породахландрас і найвища $(32,0$ од/0,1 мл×год) в еякулятах кнурів порід п’єтрен та макстер.

Отже, для сперми кнурів породи дюрок характерна висока активність як споживання кисню, так і СДГ, а відновна здатність і активність ЦХО - для породи макстер. Ймовірно, статеві клітини, залежно від породи кнурів, відрізняються шляхами використання субстратів - у сперміїв породи дюрок інтенсивніше ресинтезується АТФ через СДГ-оксидазний шлях окиснення субстратів, а у сперміях породи макстер - активний гліколіз (відновна здатність) та дихальний ланцюг мітохондрій i, відповідно, його термінальна ланка (ЦХО). Крім породних особливостей метаболізму клітин, причиною встановлених відмінностей можуть бути різниці в типах нервової системи і недотримання умов підготовки самців до садки на штучну вагіну i за еякуляції. Наслідком вказаних порушень у еякуляті може виникати дисбаланс між об'ємами виділених секретів окремих додаткових статевих залоз, що в підсумку проявляється дефіцитом чи надлишком субстратів окиснення як для забезпечення енергетичних потреб сперміїв, так і вільнорадикального окиснення.

Особливості окисних процесів в спермі характеризують виживання статевих клітин, величина якого понижена (74,4 99,26 год) у еякулятах кнурів породи дюрок, вища на 9,6 - 11,4 год $(11,5-13,3$ \%) в спермі породи п’єтрен і помісних: велика біла породахландрас і найвища (90,3 - 92,0 год) - у спермі кнурів породи макстер та ландрас. 


\title{
В И С Н О В К И
}

1. Встановлено, що вищим об'ємом еякуляту характеризуються помісні кнурі велика біла породахландрас $(207,0 \pm 29,21$ мл), а концентрацією сперміїв - породи п’єтрен і макстер $\left(0,40-0,43 \times 10^{9} /\right.$ мл). Кількість живих сперміїв в еякулятах кнурів досліджених порід не відрізняється $(78,7-80,3 \%)$.

2. Максимальні величини дихальної активності $\left(0,66 \pm 0,09\right.$ нг-атом $\mathrm{O}_{2} / 0,1$ мл×хв) i активності СДГ $(17,9 \pm 3,43$ од/ 0,1 мл×Год) характерні для сперми кнурів породи дюрок, а відновної здатності $(0,11 \pm 0,03 \mathrm{mV} / 0,1$ мл×хв) і активності ЦХО $(32,9 \pm 5,15$ од/0,1 мл×год) для породи макстер.

3. Найвище виживання сперміїв (90,3 - 92,0 год) встановлено у спермі кнурів порід макстер та ландрас.

Перспективи досліджень. Вивчити запліднювальну здатність сперміїв кнурів у зв’язку 3 породною належністю.

\section{QUALITY OF BOAR EJACULATES DEPENDING ON THE BREED}

\author{
S. Kornjat ${ }^{1}$, N. Kuzmina ${ }^{1}$, M. Sharan ${ }^{1}$, D. Ostapiv ${ }^{1}$, S. Kava ${ }^{2}$, O. Chajkovska ${ }^{3}$, \\ O. Panych ${ }^{3}$, I. Atamaniuk ${ }^{3}$, T. Stetsko ${ }^{3}$ \\ ${ }^{1}$ Institute of Animal Biology of NAAS, \\ 38, Stusa st., Lviv, 79043, Ukraine
}

${ }^{2}$ Lviv National University of Veterinary Medicine and Biotechnologies named after S. Z. Gzhytskyi 50, Pekarska st., Lviv, 79010, Ukraine

${ }^{3}$ State Scientific Research Control Institute of Veterinary Medicinal Products and Feed Additives, 11, Donetska st., Lviv, 79019, Ukraine

\section{S U M M A R Y}

The physiological and biochemical characteristics of boar ejaculates were studied in relation to the breed (pietrain, maxter, landrace, duroc and dung: large white breed $\times$ landrace). It has been established that the physiological indicators of ejaculate quality depend on the breed of boars. Higher ejaculate volume was found in large white breeds boar $\times$ landras $(207.0 \pm 29.21 \mathrm{ml})$, and spermatozoa concentration in maxter and pietrain $\left(0.40-0.43 \times 10^{9} / \mathrm{ml}\right)$. The number of live spermatozoa in the ejaculates of boars of the studied breeds did not differ (78.7-80.3\%). Maximum values of respiratory activity $\left(0.66 \pm 0.09 \mathrm{ng}\right.$-atom $\left.\mathrm{O}_{2} / 0.1 \mathrm{ml} \times \mathrm{min}\right)$ and succinate dehydrogenase activity $(\mathrm{SDH} ; 17.9 \pm 3.43$ $\mathrm{UI} / 0.1 \mathrm{ml} \times \mathrm{h})$ were typical for duroc, and redox ability $(0.11 \pm 0.03 \mathrm{mV} / 0.1 \mathrm{ml} \times \mathrm{min})$ and cytochrome oxidase activity $(\mathrm{CO} ; 32.9 \pm 5.15 \mathrm{UI} / 0.1 \mathrm{ml} \times \mathrm{h})$ for maxter.

Probably, spermatozoa, depending on the breed of boars, differ in the ways of use of substrates - in sperm of durok breed the ATP is oxidized more intensely through the SDG-oxidase pathway of substrate oxidation, and in sperm of the breed maxter - glycolysis (redox ability) and respiratory chain (its terminal link (CCO) are more active. In addition to breed characteristics of cell metabolism, differences in types of nervous system and non-compliance with the conditions of males preparation for ejaculation in artificial vagina may be the cause of the established differences. These ejaculatory disorders may result in an imbalance between the amounts of secretions of the individual additional gonades, resulting in a deficiency or excess of oxidizing substrates both to meet the energy needs of the sperm and free radical oxidation.

The highest sperm survival rate $(90.3-92.0 \mathrm{~h})$ was registered in ejaculates of maxster and landrace breeds.

Keywords: QUALITY OF EJACULATES, SPERM, BREED, BOARS. 


\title{
КАЧЕСТВО ЭЯКУЛЯТОВ ХРЯКОВ В ЗАВИСИМОСТИ ОТ ПРОИСХОЖДЕНИЯ
}

\author{
С. Б. Корнят ${ }^{1}$, Н. В. Кузьмина ${ }^{1}$, М. М. Шаран ${ }^{1}$, Д. Д. Остапив ${ }^{1}$, С. Й. Кава ${ }^{2}$, \\ О. И. Чайковская ${ }^{3}$, О. П. Паныч ${ }^{3}$ И. Е. Атаманюк, Т. И. Стецько \\ ${ }^{1}$ Институт биологии животных НААН \\ ул. В. Стуса, 38, г. Львов, 79034, Украина \\ 2 Львовский национальный университет ветеринарной медицины \\ и биотехнологий имени С. З. Гжицкого \\ ул. Пекарская, 50, г. Львов, 79010, Украина \\ ${ }^{3}$ Государственный научно-исследовательский контрольный институт ветеринарных \\ препаратов и та кормовых добавок \\ ул. Донецкая, 11, г. Львов, 79019, Украина
}

\section{А Н Н О Т А ЦИ Я}

Исследовали физиолого-биохимические характеристики эякулятов хряков в связи с породной принадлежностью (пьетрен, макстер, ландрас, дюрок и помесь: большая белая порода×ландрас). Установлено, что физиологические показатели качества эякулятов зависят от породы хряков. Высшим объемом эякулята характеризуются поместные хряки большая белая породахландрас $(207,0 \pm 29,21$ мл), а концентрацией спермиев - породы пьетрен и макстер $\left(0,40\right.$ - 0,43 × $10^{9} /$ мл). Количество живых спермиев в эякуляте хряков исследованных пород не отличается $(78,7-80,3 \%)$.

Максимальные величины дыхательной активности $\left(0,66 \pm 0,09\right.$ нг-атом $\mathrm{O}_{2} / 0,1$ мл $\times$ мин) и активности СДГ $(17,9 \pm 3,43$ ед / 0,1 мл $\times$ ч) характерны для спермы хряков породы дюрок, а восстановительной способности $(0,11 \pm 0,03 \mathrm{mV} / 0,1$ мл $\times$ мин $)$ и активности ЦХО $(32,9 \pm 5,15$ ед / 0,1 мл × ч) - для породы макстер.

Возможно, половые клетки, в зависимости от породы хряков, отличаются путями использования субстратов - в спермиев породы дюрок интенсивнее ресинтезуеться АТФ через СДГ-оксидазный путь окисления субстратов, а в спермиях породы Макстер - активный гликолиз (восстановительная способность) и дыхательная цепь митохондрий и, соответственно, ее терминальное звено (ЦХО). Кроме породных особенностей метаболизма клеток, причиной установленных отличий могут быть различия в типах нервной системы и несоблюдение условий подготовки самцов к сады на искусственную вагину и при эякуляции. Следствием указанных нарушений в эякуляте может возникать дисбаланс между объемами выделенных секретов отдельных дополнительных половых желез, что в итоге проявляется дефицитом или избытком субстратов окисления как для обеспечения энергетических потребностей спермиев, так и свободнорадикального окисления.

Высшее выживание спермиев (90,3 - 92,0 ч) установлено в сперме хряков пород макстер и ландрас.

Ключевые слова: КАЧЕСТВО ЭЯКУЛЯТОВ, СПЕРМИИ, ПОРОДА, ХРЯКИ.

\section{ЛITЕР А Т У Р А}

1. Остапчук П. П. Выращевание и племенное использование хряков. Киев, Изд. УСХА. - 1992. - $167 \mathrm{c}$.

2. Шаферівський Б. С. Якість сперми кнурів у залежності від породи та сезону року // 3б. наук. пр. ВНАУ. Сучасні проблеми селекції, розведення та гігієни тварин. — 2012.— № 4 (62) - C. 150-153. 
3. Стрижак T. A. Відтворювальні якості кнурів породи ландрас вітчизняної та зарубіжної селекції / Т. А. Стрижак, І. М. Мартинюк, О. С. Мірошникова // Свинарство. 2014. - Вип. 64. - С. 57-60.

4. Шостя А. М. Прооксидантно-антиоксидантний гомеостаз у свиней //Автореф. дис. док. с.-г. н., Львів. - 2015. - 39 с.

5. Шостя А. М. Динаміка якості спермопродукції у кнурів-плідників залежно від пори року та інтенсивності їх використання / А. М. Шостя, В. О. Рокотянська // Свинарство. 2018. - Вип. 71. - С. 116-123

6. Лукъянова Л. Д. Кислородзависимые процессы в клетке и ее функциональное состояние / Л. Д. Лукъянова, Б. С. Балмуханов, Л. Т. Уголев. - М.: Наука, 1982. - 262 с.

7. Штольи K. Ф. Амперометрическое определение ферроцианида в присутствии субклеточных структур / К. Ф. Штольц, И. М. Мосолова, Л. А. Дронова // Биохимические методы. - М.: Наука, 1980. - С. 147-150.

8. Чухрій Б. М. До методики визначення активності окислювальних ферментів у спермі бугаїв / Б. М. Чухрій, Л. О. Клевець // Розведення та штучне осіменіння великої рогатої худоби. - Київ, 1978. - Вип. 10. - С. 42-45.

9. Плохинский Н. А. Руководство по биометрии для зоотехников. - М.: Колос, 1969. $255 \mathrm{c}$.

\section{References}

1. Ostaptchuk P. P. Vyratchvanie i plemennoe ispolzovanie hrjakov. Kyjiv, Izd. USHA. 1992. - 167 s. (in Russian).

2. Shaferivskij B. S. Jakist spermy knuriv u zaleznosti vid porody ta sezonu roku // Zb. nauk. pr. VNAU. Sutchasni problemy selekcii, rozvedennja ta higieny tvaryn. - 2012.— № 4 (62). — S. 150-153. (in Ukrainian).

3. Stryzak T. A. Vidtvoruvalni jakosti knuriv porody landras vitchyznjanoi ta zarubiznoi selekcii / T. A. Stryzak, I. M. Martynjuk, O. S. Miroshnykova // Svynarstvo. — 2014. - Vyp. 64. - S. 57 - 60. (in Ukrainian).

4. Shostya A. M. Prooksydantno-antyoksydantnyi homeostaz u svynei //Avtoref. dys. dok. s.-h. n., Lviv. - 2015. - 39 s. (in Ukrainian).

5. Shostya A. M. Dynamika jakosti spermoprodukcii u knuriv-plidnykiv zalezno vid pory roku ta intensyvnosti ich vykorystannja / A. M. Shostya, V.O. Rokotjanska // Svynarstvo. — 2018. - Vyp. 71. - S. 116 - 123 (in Ukrainian).

6. Lukjanova L. D. Kislorodzavisimyje processy v кletke i ejo funkcionalnoe sostojanije / L. D. Lukjanova, B. S. Balmuhanov, L. T. Ugolev. — M.: Nauka, 1982. — 262 s. (in Russian).

7. Shtolc K. F. Amperiometricheskoe opredelenie ferrocianida v prisutstvii subkletochnyh struktur / K. F. Shtolc, I. M. Mosolova, L. A. Dronova. Biohimicheskije metody. - M.: Nauka, 1980. - S. 147 - 150. (in Russian).

8. Chuhrij B. M. Do metodyky vyznachennja aktyvnosti okysluvalnyh fermentiv u spermi buhajiv / B. M. Chuhrij, L. O. Klevec // Rozvedennja ta shtuchne osimeninnja velykoji rohatoji hudoby. - Kyjiv, 1978. - Vyp. 10. - S. 42-45. (in Ukrainian). (in Russian).

9. Plohinskij N. A. Rukovodstvo po biometriji dla zootehnicov. - M.: Kolos, 1969. -255 s.

Рецензент - I. М. Кушнір, д.вет.н., ДНДКІ ветпрепаратів та кормових добавок. 